\title{
ДЕМОГРАФИЧЕСКИЙ ФАКТОР КАК СТРАТЕГИЧЕСКИЙ ЭЛЕМЕНТ СОЦИАЛЬНО-ЭКОНОМИЧЕСКОГО РАЗВИТИЯ РЕГИОНА
}

\author{
I.V. Kovaleva
}

\section{DEMOGRAPHIC FACTOR AS STRATEGIC ELEMENT OF SOCIAL AND ECONOMIC DEVELOPMENT OF THE REGION}

Социально-экономическое развитие сельских территорий определяется многими факторами, но преобладающее влияние оказывает демографическая ситуация, при этом во многом определяя развитие рынка трудовых ресурсов. В Алтайском крае на протяжении ряда лет складывается неблагоприятная демографическая ситуация, обусловленная высоким уровнем смертности населения, снижением уровня рождаемости, миграционными процессами. Наиболее остро эта проблема существует в трансграничных районах региона. Сложивииеся тренды позволяют говорить о критической ситуации демографического процесса. Миграционный отток для подавляющего большинства муниципалитетов является основной причиной сокращения численности населения. В муниципальных образованиях, как и в целом по краю, отмечается снижение численности трудоспособного населения. Сuтуация на рынке труда Южной зоны края аналогична ситуации в цеелом по Алтайскому краю: на фоне снижения численности трудоспособного населения отмечается снижение численности работников крупных и средних предприятий. Отраслевой срез занятости показывает, что более половины населения (52 \%) занято в организациях бюджетного сектора. На предприятиях обрабатывающей промыиленности занято 14 \% общей численности работников, что сопоставимо со средним показателем по Алтайскому краю. Доля работников крупных и средних организаций, занятых в секторе сельского хозяйства, составляет 9,4 \%, что превышает показатель по Алтайскому краю (6,5 \%). Социально-экономическое развитие региона во многом определяется развитием социальной инфраструктуры. Создание комфортньх условий трудовой деятельности и жизни в сельской местности является приоритетным условием стратегического развития региона. Наиболее важньм является дальнейшая реализация мероприятий развития транспортной инфраструктуры, социальных и культурных объектов.

Ключевые слова: сельские территории, развитие, демографические процессы, рынок труда, социальная инфраструктура. 
Social and economic development of rural territories is defined by many factors, but demographic situation has prevailing impact, thus in many respects defining the development of the market of the labor re sources. In Altai Region for a number of years there has been an unfavorable demographic situation due to high mortality rate of the population, the decline in the birth rate and migration processes. The problem is most acute in cross-border areas of the region. Current trends give the chance to speak about critical situation of demographic process. Migration outflows for the vast majority of municipalities are the main reason for the population decline. The situation in the labor market of the Southern region is similar to the situation in Altai Region as a whole: against the background of the decline in working population, there is a decline in the number of employees of large and medium-sized enterprises. The industry cut of employment shows that more than half of the population (52\%) is employed in the organizations of the budgetary sector. The enterprises of manufacturing industry employs 14 per cent of the total working force, which is comparable to the Altai Region average value. The share of employees of large and mediumsized organizations employed in agricultural sector makes $9.4 \%$ exceeding this indicator across Altai Region (6.5\%). Social and economic development of the region in many respects is defined by the development of social infrastructure. Creating comfortable working and rural environment is the priority for strategic development of the region. The most important is further implementation of the development of transport infrastructure, social and cultural facilities.

Keywords: rural areas, development, demographic processes, labor market, social infrastructure.

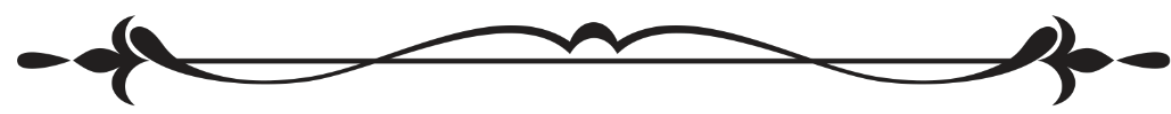

Эффективное развитие региона во многом определяется его социально-экономическим состоянием и стратегическими мероприятиями. При этом большое влияние оказывают ряд макрофакторов, в том числе демографический фактор, затрагивая при этом рынок трудовых ресурсов.

Теоретическую и методологическую основу исследования составили труды отечественных и зарубежных ученых по проблемам ведения сельскохозяйственного производства органической продукции, вопросам развития земельных отношений; научные исследования и рекомендации Российской академии сельскохозяйственных наук, законы Российской Федерации, указы Президента и постановления Правительства Российской Федерации, нормативно-правовые акты субъектов федерации. Методологической основой послужил системный подход, позволивший обеспечить комплексность и целенаправленность. В исследовании также были использованы аналитический, абстрактно-логический, 


\section{Социально-экономический и әуманитарный журнал Красноярского ГАУ. 2020. №1}

расчетно-конструктивный, экономико-статистический, экономикоматематический, монографический методы исследования.

Трансграничные сельские территории традиционно имеют особенности развития, обусловленные рядом факторов: географическое трансграничное положение, удаленность от крупных населенных пунктов региона, слабая социальная и транспортная инфраструктура, узкая отраслевая специализация и др.

Для трансграничных сельских территорий характерна депопуляция на протяжении всего постсоветского периода (в среднем территории теряют около 1 \% населения). По переписи 2002 г. на территории Ю3 проживало почти 470 тыс. чел., к 2010 г. численность населения данных территорий уменышилась с 421 тыс. (2010 г.) до 393 тыс. чел. (2017 г.) [1]. Только за последние 5 лет потери населения трансграничных сельских территорий составляют более 5,4 \%, при этом Краснощековский, Локтевский, Третьяковский, Угловский районы потеряли свыше 8 \% населения, Курьинский - свыше 12 \% [2]. Продолжается негативная тенденция в целом по региону: показатель коэффициента рождаемости за последние 5 лет составил 12,1\%; смертности - 15,9\%[1].

Сложившиеся тренды позволяют говорить об исчерпании внутренних резервов демографического роста. Однако миграционный отток для подавляющего большинства муниципалитетов является основной причиной сокращения численности населения. Ежегодно миграционные потери свыше 10 \% характерны для Волчихинского, Краснощековского, Локтевского, Третьяковского и Угловского районов, а в Курьинском районе данный показатель превышает 20 \%.

Положительное сальдо миграции характерно лишь для г. Рубцовска и Шипуновского района [1]. Ситуация осложняется старением населения сельских территорий: средний возраст жителей - 48 лет. Кроме того, наблюдается значительный половой диспаритет - 112 женщин на 100 мужчин [1] (рис. 1).

Доля жителей трудоспособного возраста - 54,2 \%; старше трудоспособного - 27,8; младше - 18,9 \%. В наиболее депопулирующих районах - Курьинском, Локтевском, Краснощековском доля лиц старше трудоспособного возраста достигает 30-34 \%, при этом коэффициент демографической нагрузки превышает 900 (число лиц нетрудоспособного возраста, приходящееся на 1000 лиц трудоспособного возраста).

В муниципальных образованиях, как и в целом по краю, отмечается снижение численности трудоспособного населения. Ситуация на рынке труда края имеет негативную тенденцию: на фоне снижения численности трудоспособного населения отмечается снижение численности работников крупных и средних предприятий. 
2016

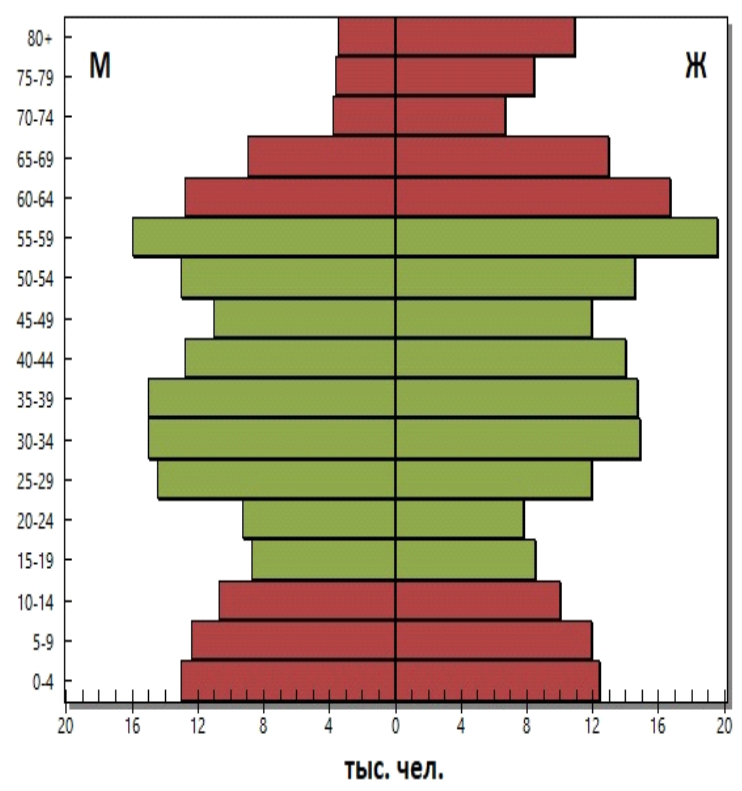

2025

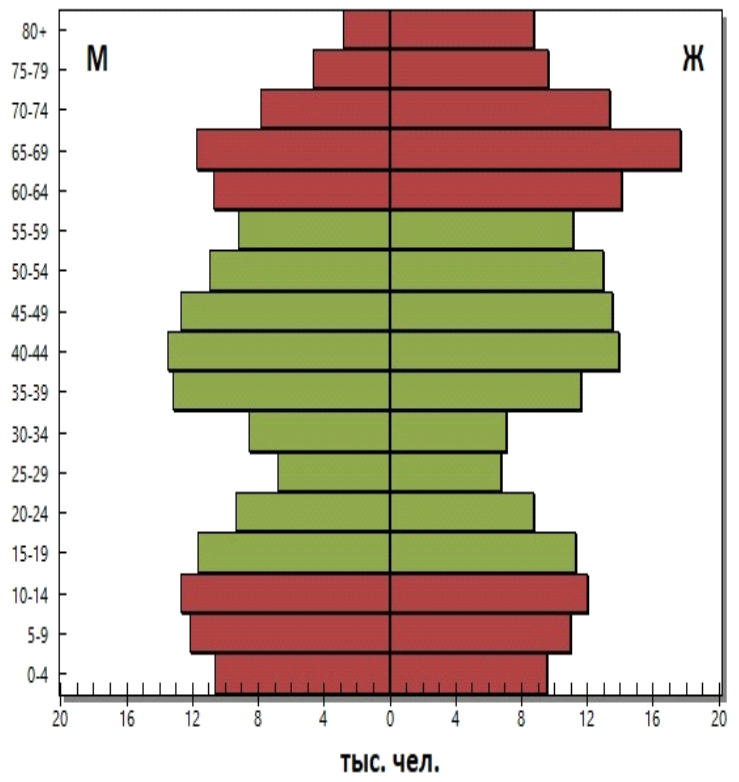

Рис. 1. Половозрастная структура населения сельских территорий [1]

Отраслевой срез занятости демонстрирует, что более половины населения - 52,4 \% занято в организациях бюджетного сектора. На предприятиях обрабатывающей промышленности занято 14 \% общей численности работников, что сопоставимо со средним показателем по Алтайскому краю. Основная доля работников занята в отраслях сельского хозяйства (около 10 \%), что превышает показатель по Алтайскому краю (6,5\%).

В абсолютном значении количество занятых снизилось более, чем на 19 \% [1]. Отрицательная динамика прослеживается во всех отраслях, кроме оптовой и розничной торговли и операций с недвижимым имуществом, арендой и предоставлением услуг. Наибольшее сокращение среднесписочной численности работников произошло в таких отраслях, как добыча полезных ископаемых, обрабатывающие производства, сельское хозяйство, охота и лесное хозяйство, образование и здравоохранение (табл. 1).

Социальные условия оказывают влияние на темпы социальноэкономического развития сельских территорий. Так, обеспеченность жильем населения муниципальных образований исследуемых районов Алтайского края в целом ниже, чем в среднем по муниципальным образованиям региона.

В муниципальных образованиях прослеживается связь между среднегодовыми темпами убыли населения и обеспеченностью жильем. В частности, районы, характеризующиеся высокими темпами убыли населения, отличаются более высоким уровнем обеспеченности населения жильем (рис. 2). 


\section{Динамика уровня безработицы сельских территорий, \% трудоспособного населения [1]}

\begin{tabular}{|l|c|c|c|c|}
\hline \multicolumn{1}{|c|}{ Территория } & 2011 г. & 2013 г. & 2015 г. & 2017 г. \\
\hline В среднем по региону & 2,3 & 1,7 & 1,5 & 1,5 \\
\hline Волчихинский & 3,4 & 3,6 & 3,1 & 3,2 \\
\hline Егорьевский р-н & 4,4 & 3,5 & 3,1 & 3,0 \\
\hline Змеиногорский р-н & 3,2 & 3,2 & 3,1 & 2,8 \\
\hline Краснощековский р-н & 2,5 & 1,8 & 1,9 & 1,8 \\
\hline Курьинский р-н & 2,8 & 2,5 & 2,3 & 2,9 \\
\hline Локтевский р-н & 3,2 & 3,1 & 2,7 & 2,6 \\
\hline Михайловский р-н & 5,4 & 4,0 & 3,8 & 3,4 \\
\hline Новичихинский р-н & 5,2 & 5,1 & 4,2 & 3,8 \\
\hline Поспелихинский р-н & 2,6 & 2,6 & 1,8 & 1,9 \\
\hline Рубцовский р-н & 2,3 & 2,4 & 2,3 & 2,2 \\
\hline Третьяковский р-н & 1,8 & 1,8 & 1,4 & 1,5 \\
\hline Угловский р-н & 2,4 & 2,8 & 3,3 & 3,2 \\
\hline Чарышский р-н & 3,2 & 3,0 & 2,4 & 2,8 \\
\hline Шипуновский р-н & 3,1 & 1,2 & 0,9 & 0,8 \\
\hline
\end{tabular}

Обеспеченность жильем и убытие населения

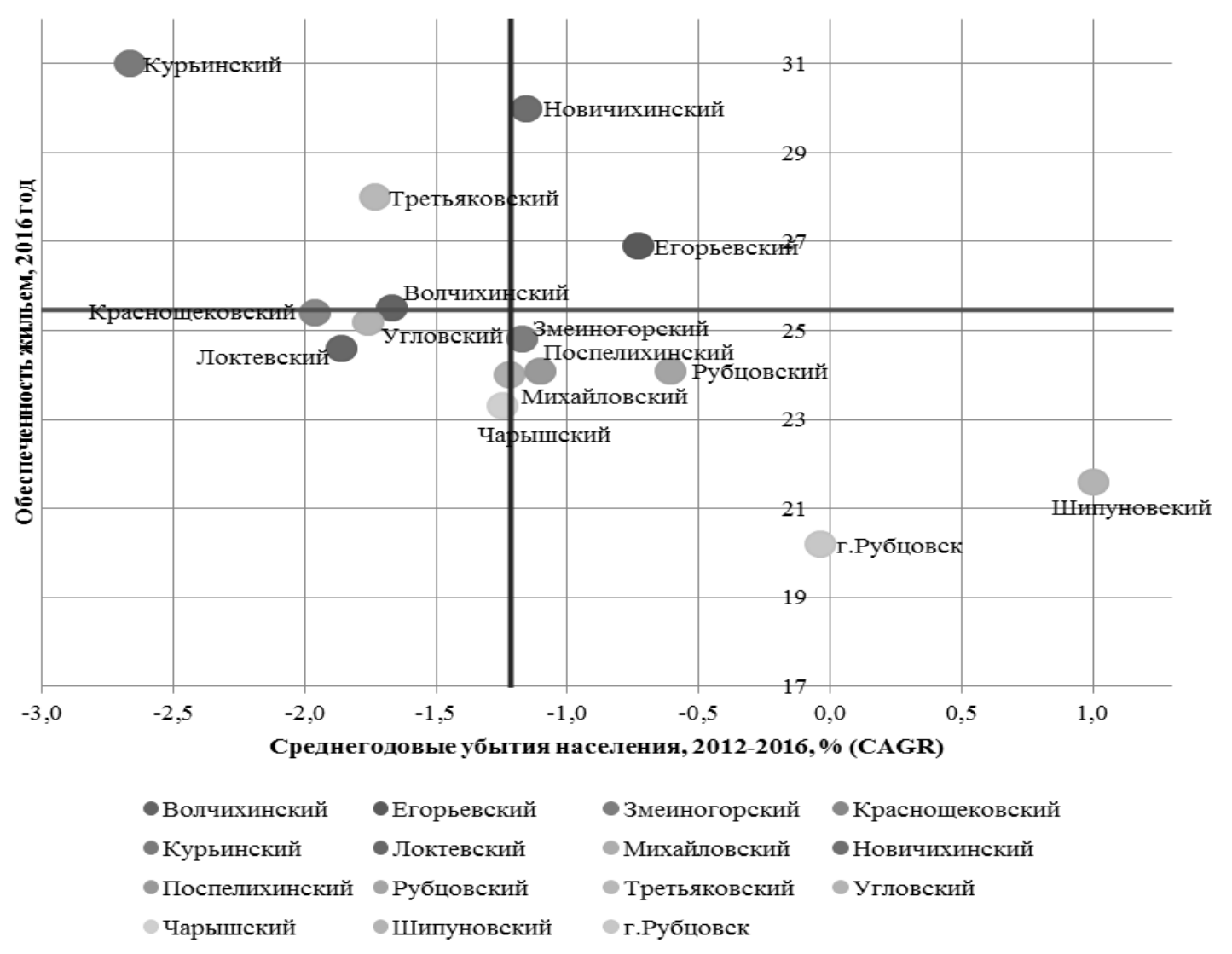

Рис. 2. Обеспеченность населения жильем в разрезе муниципальных образований Алтайского края [1] 
С 2014 г. во всех муниципальных районах и городских округах Алтайского края внедрены 15 разделов регионального инвестиционного стандарта, разработанного АНО «Агентство стратегических инициатив по продвижению новых проектов». Показатели Национального рейтинга состояния инвестиционного климата в субъектах РФ демонстрируют, что Алтайский край занимает средние позиции и ниже по различным критериям.

Инвестиции в основной капитал на душу населения среди муниципальных образований характеризуются высокой степенью неоднородности. В частности, в Змеиногорском районе объем инвестиций в основной капитал на душу населения составил 50,8 тыс. руб.; в Курьинском районе - 3 тыс руб. (рис. 3).

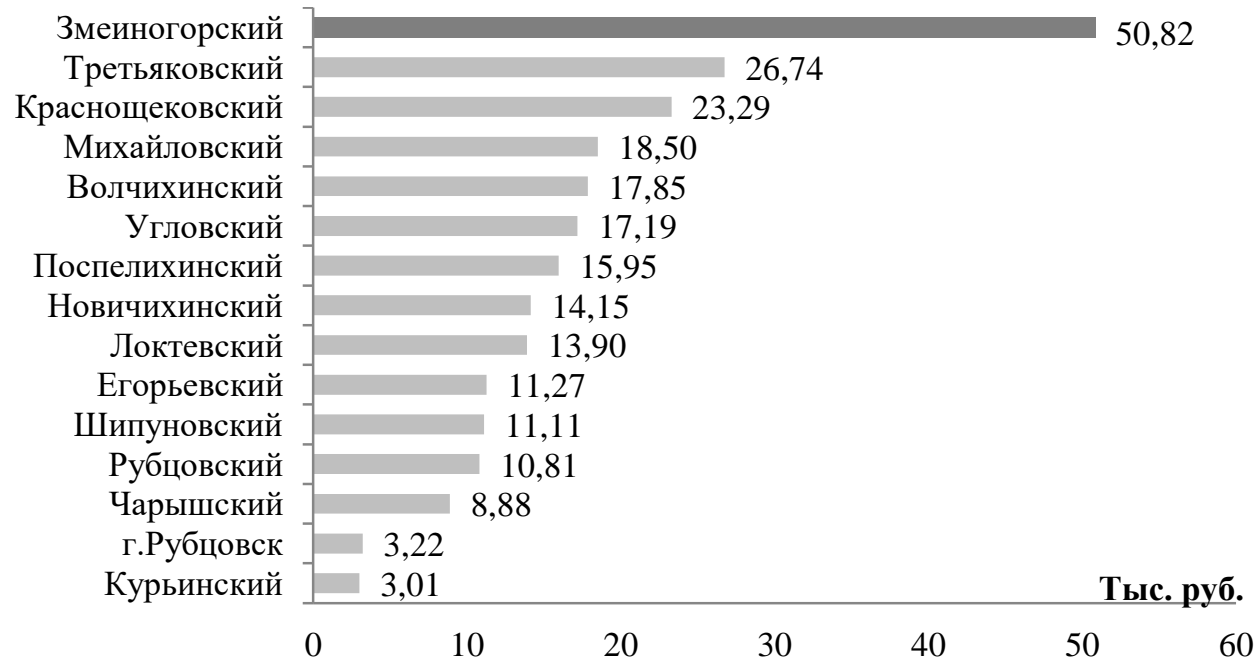

Рис. 3. Объем инвестиций в основной капитал в расчете на душу населения в 2016- 2018 г2., в среднем [1]

Высокий уровень инвестиций в основной капитал на душу населения в Змеиногорском районе связан с разработкой месторождений, в частности, реализуется проект по освоению Корбалихинского месторождения полиметаллических руд ОАО «Сибирь-Полиметаллы», также компания продолжает разработку Зареченского и Степного месторождений.

Высокие транспортные издержки, отсутствие контейнерных перевозок, длительный срок доставки продукции железнодорожным транспортом снижают ожидаемую рентабельность инвестиционных проектов, что в свою очередь снижает инвестиционную активность. Также спрос на продукцию в Алтайском крае, как и в соседних регионах, в долгосрочной перспективе сократится в связи с убылью населения, а конкуренция за инвестора с Казахстаном дополнительно затруднит привлечение инвесторов в районы.

Институциональная структура сельскохозяйственного производства характеризуется сокращением доли сельскохозяйственных организа- 


\section{Социально-экономический и әуманитарный журнал Красноярского ГАУ. 2020. №1}

ций в объеме производства сельскохозяйственной продукции (с 37 до 33,7 \%) при одновременном увеличении доли фермерских хозяйств (с 13 до $19,1 \%)$.

Социальная инфраструктура исследуемых районов представлена 69 организациями здравоохранения (19 \% от общего количества организаций здравоохранения Алтайского края), в том числе 10 организациями здравоохранения федеральной собственности, 57 организациями здравоохранения, находящихся в региональной собственности, а также 2 организациями здравоохранения муниципальной собственности.

\section{Количество организаций здравоохранения в муниципальных образованиях, 2017 г. [1, 4]}

Таблица 2

\begin{tabular}{|c|c|c|c|c|}
\hline \multirow{2}{*}{$\begin{array}{c}\text { Муниципальное } \\
\text { образование }\end{array}$} & \multirow[b]{2}{*}{ Всего } & \multicolumn{3}{|c|}{$\begin{array}{c}\text { В том числе по формам } \\
\text { собственности организаций }\end{array}$} \\
\hline & & федеральная & $\begin{array}{c}\text { субъектов } \\
\text { Российской } \\
\text { Федерации }\end{array}$ & муниципальная \\
\hline Волчихинский р-н & 3 & - & 3 & - \\
\hline Егорьевский р-н & 4 & - & 4 & - \\
\hline Змеиногорский р-н & 4 & 1 & 2 & 1 \\
\hline Краснощековский р-н & 2 & - & 2 & - \\
\hline Курьинский р-н & 1 & - & 1 & - \\
\hline Локтевский р-н & 5 & 1 & 3 & 1 \\
\hline Михайловский р-н & 8 & 1 & 7 & - \\
\hline Новичихинский р-н & 2 & - & 2 & - \\
\hline Поспелихинский р-н & 2 & 1 & 1 & - \\
\hline Рубцовский р-н & 1 & - & 1 & - \\
\hline Третьяковский р-н & 1 & - & 1 & - \\
\hline Угловский р-н & 1 & - & 1 & - \\
\hline Чарышский р-н & 1 & - & 1 & - \\
\hline Шипуновский р-н & 4 & 1 & 3 & - \\
\hline г. Рубцовск & 30 & 5 & 25 & - \\
\hline Алтайский край & 367 & 57 & 295 & 15 \\
\hline
\end{tabular}

Средняя мощность амбулаторно-поликлинических учреждений Южной зоны составляет 271 посещений в смену на 10 тыс. населения. В разрезе муниципальных образований по показателю мощности поликлинических учреждений выделяется Курьинский район (509,6 посещений в смену на 10 тыс. населения), в котором данный показатель в 1,9 раз превышает средний показатель по Южной зоне. Наименьшие показатели мощности отмечаются в Поспелихинском и Краснощековском районах - 160,2 и 156,5 посещений в смену на 10 тыс. населения соответственно.

Обеспеченность сельского населения учреждениями культуры и спорта сильно различается в зависимости от муниципального образования. 
Таблица 3

\section{Обеспеченность библиотеками, учреждениями культуры и спорта [1, 5]}

\begin{tabular}{|c|c|c|c|c|c|c|c|c|}
\hline \multirow[b]{2}{*}{$\begin{array}{c}\text { Муниципальное } \\
\text { образование }\end{array}$} & \multicolumn{2}{|c|}{ Библиотеки } & \multicolumn{2}{|c|}{$\begin{array}{l}\text { Учреждения } \\
\text { культуры }\end{array}$} & \multicolumn{2}{|c|}{$\begin{array}{l}\text { Спортивные } \\
\text { сооружения }\end{array}$} & \multicolumn{2}{|c|}{$\begin{array}{c}\text { Занято } \\
\text { спортом }\end{array}$} \\
\hline & $\begin{array}{c}\text { на } \\
10 \\
\text { тыс. } \\
\text { чел. }\end{array}$ & $\begin{array}{c}\text { \% факт. } \\
\text { обеспе- } \\
\text { ченности }\end{array}$ & $\begin{array}{c}\text { на } 10 \\
\text { тыс. } \\
\text { чел }\end{array}$ & $\begin{array}{c}\text { \% факт. } \\
\text { обеспе- } \\
\text { ченности }\end{array}$ & Ед. & $\begin{array}{c}\text { Прирост } \\
\text { за 5 лет, } \\
\text { \% }\end{array}$ & $\begin{array}{l}\text { \% об- } \\
\text { щего } \\
\text { числа }\end{array}$ & $\mid \begin{array}{c}\text { Прирост } \\
\text { за 5 лет, } \\
\%\end{array}$ \\
\hline г. Рубцовск & 0,7 & 10 & 0,3 & 4 & 441 & 0,7 & 10 & 0,3 \\
\hline Волчихинский p-н & 7 & 13 & 8 & 15 & 102 & 7 & 13 & 8 \\
\hline Егорьевский р-н & 6 & 8 & 8 & 10 & 68 & 6 & 8 & 8 \\
\hline Змеиногорский p-н & 10 & 16 & 10 & 19 & 139 & 10 & 16 & 10 \\
\hline $\begin{array}{l}\text { Краснощековский } \\
\text { p-н }\end{array}$ & 10 & 17 & 11 & 18 & 70 & 10 & 17 & 11 \\
\hline Курьинский р-н & 15 & 14 & 8 & 14 & 116 & 15 & 14 & 8 \\
\hline Локтевский р-н & 6 & 16 & 8 & 21 & 90 & 6 & 16 & 8 \\
\hline Михайловский p-н & 5 & 9 & 5 & 9 & 102 & 5 & 9 & 5 \\
\hline Новичихинский p-н & 10 & 9 & 14 & 13 & 47 & 10 & 9 & 14 \\
\hline $\begin{array}{l}\text { Поспелихинский } \\
\text { p-н }\end{array}$ & 6 & 13 & 7 & 15 & 99 & 6 & 13 & 7 \\
\hline Рубцовский р-н & 8 & 19 & 15 & 36 & 111 & 8 & 19 & 15 \\
\hline Третьяковский р-н & 12 & 15 & 13 & 17 & 85 & 12 & 15 & 13 \\
\hline Угловский р-н & 14 & 18 & 14 & 17 & 75 & 14 & 18 & 14 \\
\hline Чарышский р-н & 21 & 23 & 24 & 27 & 130 & 21 & 23 & 24 \\
\hline Шипуновский р-н & 10 & 32 & 10 & 32 & 130 & 10 & 32 & 10 \\
\hline
\end{tabular}

В целях оптимизации культурного обслуживания населения и создания условий для обеспечения доступа к культурным благам и информационным ресурсам, сохранения историко-культурного наследия муниципальными образованиями зоны реализуются муниципальные программы «Развитие культуры» [1].

Выполнение муниципальными районами обязательств в области культуры и спорта осложняется, как и в случае с образованием, неэффективным расселением граждан. В малонаселенных пунктах возникает проблема к полноценному доступу жителей к услугам культуры и спорта.

Немаловажным фактором, влияющим на условия проживания в сельской местности, является транспортная инфраструктура (табл. 4). 
Основные показатели дорожной инфраструктуры [1]

\begin{tabular}{|c|c|c|c|c|c|c|}
\hline 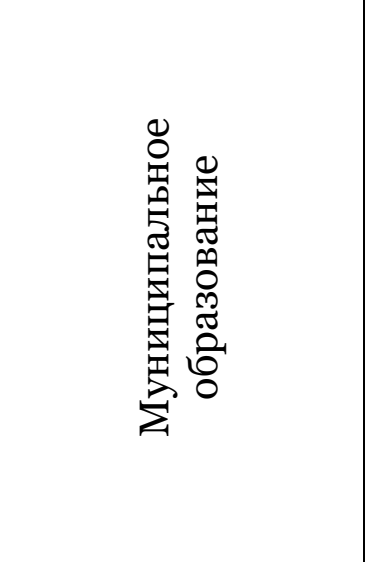 & 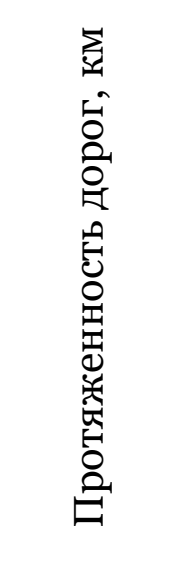 & 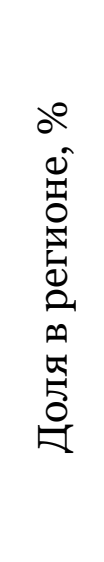 & 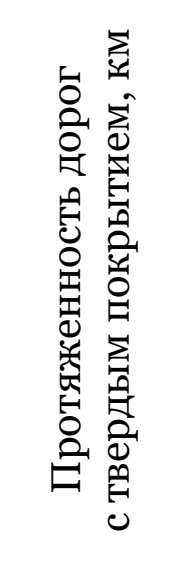 & 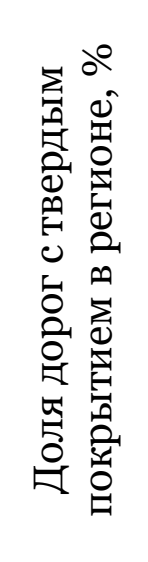 & 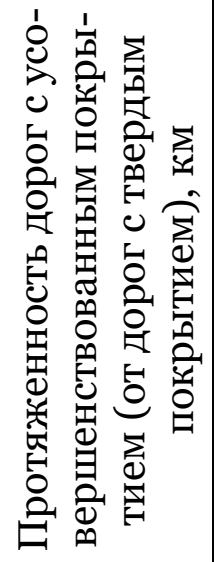 & 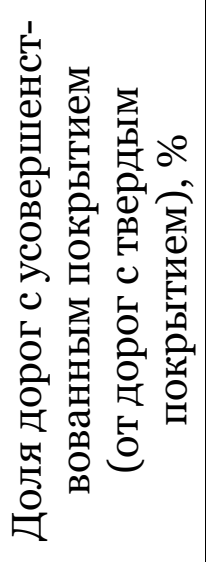 \\
\hline $\begin{array}{l}\text { Волчихинский } \\
\text { p-н }\end{array}$ & 236,735 & 1,47 & 229,042 & 96,75 & 197,576 & 86,26 \\
\hline Егорьевский р-н & 182,143 & 1,13 & 172,222 & 72,75 & 67,726 & 29,57 \\
\hline $\begin{array}{l}\text { Змеиногорский } \\
\text { p-н }\end{array}$ & 208,155 & 1,29 & 198,955 & 84,04 & 129,892 & 56,71 \\
\hline $\begin{array}{l}\text { Краснощековский } \\
\text { p-н }\end{array}$ & 339,028 & 2,10 & 317,928 & 134,30 & 105,568 & 46,09 \\
\hline Курьинский р-н & 233,723 & 1,45 & 227,753 & 96,21 & 188,454 & 82,28 \\
\hline Локтевский р-н & 241,115 & 1,49 & 226,415 & 95,64 & 121,933 & 53,24 \\
\hline $\begin{array}{l}\text { Михайловский } \\
\text { p-н }\end{array}$ & 214,981 & 1,33 & 200,583 & 84,73 & 154,323 & 67,38 \\
\hline $\begin{array}{l}\text { Новичихинский } \\
\text { p-н }\end{array}$ & 210,459 & 1,30 & 204,059 & 86,20 & 87,029 & 38,00 \\
\hline $\begin{array}{l}\text { Поспелихинский } \\
\text { p-н }\end{array}$ & 209,771 & 1,30 & 197,671 & 83,50 & 129,689 & 56,62 \\
\hline $\begin{array}{l}\text { Третьяковский } \\
\text { p-н }\end{array}$ & 233,050 & 1,44 & 210,450 & 88,90 & 110,753 & 48,35 \\
\hline Угловский р-н & 290,830 & 1,80 & 238,440 & 100,72 & 101,709 & 44,41 \\
\hline Чарышский р-н & 320,899 & 1,99 & 268,705 & 113,5 & 109,023 & 47,60 \\
\hline Шипуновский р-н & 423,470 & 2,62 & 405,400 & 171,25 & 157,999 & 68,98 \\
\hline
\end{tabular}

Удаление от основных рынков сбыта вынуждает предприятия повышать себестоимость своей продукции за счет доставки, тем самым снижая ее конкурентоспособность. Поскольку Россия и Казахстан входят в единое экономическое пространство, граница здесь выполняет контактную функцию, что служит конкурентным преимуществом трансграничных сельских территорий перед другими частями края. Кроме того, Казахстан является одним из наиболее перспективных и быстроразвивающихся рынков Средней Азии. Удаленность от курортов Западной Ев- 
ропы, Азиатских стран, Турции и Африки создает естественные конкурентные преимущества для предприятий туристической отрасли районов Алтайского края.

По данным Федеральной таможенной службы, за период с января по сентябрь 2019 г. общая стоимость отгруженной в страны ближнего и дальнего зарубежья продукции АПК составила порядка 179,7 млн долл. США, по отношению к аналогичному периоду 2018 г. отмечен рост в 1,45 раза. При этом экспорт злаков составил 192,7 тыс. т на общую стоимость 38,6 млн долл. США (рост в 2,1 раза); продукции пищевой и перерабатывающей промышленности - 47,5 млн; масложировой продукции 25,9 млн (снижение на 11 \%); мясо-молочной продукции - 4,4 млн; рыбной продукции - 1,6 млн; прочая продукция АПК - 61,7 млн долл. США (рост в 1,9 раза) (рис. 4.) [1, 2].

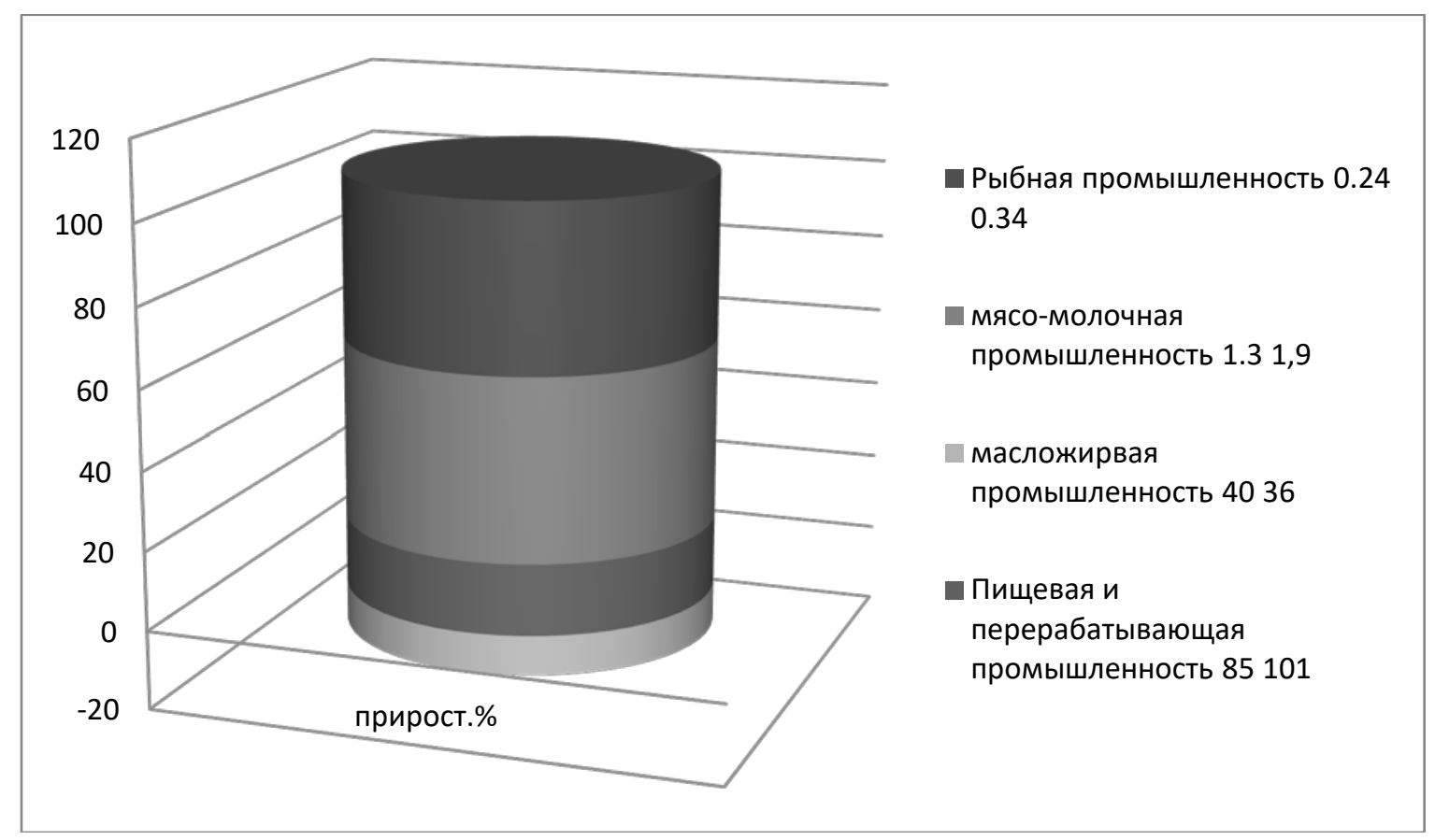

Рис. 4. Экспорт продукции АПК, 2018- 2019 ге. [1, 2]

В структуре экспорта злаков в стоимостном выражении 52,4 \% составили отгрузки пшеницы (Латвия, Азербайджан, Казахстан и др.), 18,6 ячмень (Иран, Беларусь и др.); 16,8 \% - гречиха ( Китай, Япония и др.).

Урегулирование железнодорожных тарифов, в том числе транзитных, с Республикой Казахстан достигнуто в рамках Договора о Евразийском экономическом союзе. Реализация данных мероприятий будет способствовать увеличению объемов экспорта сельскохозяйственного сырья и продовольствия, содействовать в достижении целевых показателей регионального и федерального проектов «Экспорт продукции АПК», кроме того, положительно скажется на развитии трансграничных территорий в части увеличения рабочих мест, привлечения дополнительных инвестиций в регион. 


\section{Социально-экономический и әуманитарный журнал Красноярского ГАУ. 2020. №1}

Выводы. Стратегическим направлением региона является демографическое развитие. При этом основными задачами являются проведение профилактики онкологических и сердечно-сосудистых заболеваний, выявление и лечение этих заболеваний на ранних стадиях, улучшение материально-технической базы медицинского обслуживания; повышение транспортной доступности населенных пунктов для возможности оперативного прибытия скорой медицинской помощи во все, даже труднодоступные, населенные пункты, развитие мобильных форм лечебно-диагностической и консультационной помощи; повышение качества медицинских услуг, оказываемых лицам пожилого возраста, совершенствование социального обслуживания инвалидов и пожилых людей; проведение профилактики и своевременного лечения профзаболеваний, укрепление сотрудничества медицинских служб, профсоюзов и работодателей.

Немаловажным условием улучшения демографической ситуации является повышение рождаемости и укрепление репродуктивного здоровья населения.

Стимулирование семей к рождению детей путем совершенствования системы выплаты пособий, адресная политика выплаты пособий; проведение мероприятий по улучшению жилищных условий семей с детьми путем строительства социального жилья и предоставления льгот молодым семьям, приобретающим жилье; увеличение помощи семьям, воспитывающим приемных детей, мероприятия по стимулированию усыновления и удочерения приемных детей - все эти мероприятия положительно скажутся на демографической ситуации в регионе.

\section{Литература}

1. Территориальный орган Федеральной службы государственной статистки по Алтайскому краю URL: www.gks.ru/dbscripts/munst/ munst01/ DBInet.coi\#1 (дата обращения: (22.01.2020).

2. Территориальный орган Федеральной службы государственной статистки по Алтайскому краю URL: http://akstat.gks.ru (дата обращения: 09.01.2020).

3. Управление Алтайского края по пищевой, перерабатывающей, фармацевтической промышленности и биотехнологиям URL: http:// www.ffprom22.ru/info/ analitika/ (дата обращения: 08.01.2020).

4. Министерсво здравоохранения Алтайского края URL: http:/ / zdravalt.ru// (дата обращения: 03.02.2020).

5. Министерство образования и науки Алтайского края URL: http:// www.educaltai.ru/ (дата обращения: 03.02.2020). 


\section{Literatura}

1. Territorial'nyj organ Federal'noj sluzhby gosudarstvennoj sta-tistki po Altajskomu kraju URL: www.gks.ru/dbscripts/munst/munst01/ DBInet.cgi\#1 (data obrashhenija: (22.01.2020).

2. Territorial'nyj organ Federal'noj sluzhby gosudarstvennoj sta-tistki po Altajskomu kraju URL: http://akstat.gks.ru (data obrashhe-nija: 09.01.2020).

3. Upravlenie Altajskogo kraja po pishhevoj, pererabatyvajushhej, farmacevticheskoj promyshlennosti i biotehnologijam URL: http:// www.ffprom22.ru/info/ analitika/ (data obrashhenija: 08.01.2020).

4. Ministersvo zdravoohranenija Altajskogo kraja URL: http:// zdravalt.ru// (data obrashhenija: 03.02.2020).

5. Ministerstvo obrazovanija i nauki Altajskogo kraja URL: http:// www.educaltai.ru/ (data obrashhenija: 03.02.2020).

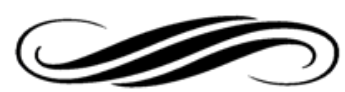

